\title{
Environmental Law Politics and Malind Anim Indigenous People Rights Protection based on Free and Prior Informed Consent Principles
}

\author{
Emiliana B. Rahail ${ }^{1 *}$, Julianto J. J. Kalalo ${ }^{1}$, Herbin F. Betaubun ${ }^{2}$, Chyntia N. Kalalo ${ }^{3}$ \\ ${ }^{1}$ Faculty of Law, Musamus University, Merauke-Indonesia \\ ${ }^{2}$ Faculty of Engineering, Musamus Unibersity, Merauke-Indonesia \\ ${ }^{3}$ Faculty of Teacher Training and Education, Musamus University, Merauke-Indonesia
}

\begin{abstract}
Indigenous peoples and the environment are two things that are difficult to separate, because they are interdependent. The regulation of environmental law in Indonesia and in the world generally regulates the protection of indigenous peoples' rights of the environment. Over time, conflicts over the environment often occur due to the needs of development that exploit the indigenous peoples' environment. The problem in this paper is to protect the rights of indigenous peoples and their customary environment based on the Principles of Free and Prior Informed Consent (FPIC). Based on FPIC principles, indigenous peoples' rights of their environment can be protected and it will not cause harm to the indigenous peoples. When governments and investors use the customary environment of the indigenous people for both public and economic development interests, they must pay respect and appreciation to the indigenous peoples in the using the environment based on FPIC principles. This research was conducted by analyzing the rules of law and the principles of law, and examining the relationship of environmental law issues and the regulations that exist. The conclusion of this paper is that the principles of FPIC is the concept of environmental protection on the rights of indigenous peoples which must be applied in the existing laws of environmental law in Indonesia to maintain legal certainty in protecting indigenous peoples' customary environment.
\end{abstract}

Keywords: Law Politics; Environmental Protection; Indigenous people; FPIC principles

\section{Introduction}

Indonesia distinct ethnics and customs and each ethnic has its own customary legal order. Based on Nusantara Indigenous Peoples Alliance data, 5-70 million of 120 million Indonesians are indigenous and tribal peoples, who have historically been indigenous peoples who have for generations lived in Indonesia. [1]

The human environment or often called the environment is a part of the natural ecosystem that must be preserved in existence. Environment is a review of human attitudes and behavior, with all responsibilities and obligations and the rights to observe the environment as well as possible. [2] These attitudes and behaviors are indispensable to enable the survival of the whole life fair, including the well-being of humans and other living beings. [3]

The environment is the unity of space with all things, power, circumstances, and living things, including human beings and their behaviors that affect the nature of life, the survival of life, and the welfare of human beings and other living beings. Based on this environmental policy according to the researcher is the effort to maintain the continuity of human environment and other living things. [4]

Indigenous peoples are the smallest part of Indonesian society. The existence of indigenous peoples in remote areas is always a matter of discrimination and it is not considered by the state. Recognition and respect for the rights of indigenous peoples in Indonesia are crystallized in the constitution, namely Article $18 \mathrm{~B}$ of Section 2 of the 1945 Constitution of the State of the Republic of Indonesia (hereinafter referred to as the 1945 Constitution of the Republic of Indonesia): "The State recognizes and respects the unity of indigenous and tribal peoples as well as their traditional rights as long as it is alive and in accordance with the development of society and the principle of the Unitary State of Republic of Indonesia"

The Malind Anim society in Merauke is one of indigenous peoples located in the eastern tip of Indonesia in Merauke Regency of Papua Province. From the beginning, the people of Malind Anim Merauke have been the living tribe and have protected the natural environment and its customary territory from generation to generation. Based on the Law Number 32 Year 2009 (Law No. 32 of 2009) on environmental protection and

* Corresponding author: rahail@unmus.ac.id 
management, article 1 point 1 , the phrase of "man and his behavior" indicates that the environment is a part of human beings and humans have the obligation to protect the environment. Based on this understanding, philosophically, the indigenous people of Malind Anim have been implementing environmental protection since long time ago and it has been the custom done from generation to generation until today.

On May 9, 2015, President Jokowi came to Merauke to harvest a rice paddy field managed by PT. Parama Pangan Papua (PPP) in Wapeko. On that occasion, the President also proclaimed Merauke to be a national rice production center or known as "national food barn" in the period of 3 years with a land area of 1.2 million ha. With that width of area, Merauke is expected to 24 tons of rice per hectare per year. Therefore, the overall production will be about 24 million tons per year. This amount is equal to $30 \%$ of national rice production (the national rice production is 70.83 million tons per year). [5]

Before the land clearing policy of 1.2 million ha is implemented, it is necessary to analyze the availability of space to avoid spatial conflicts. As previously known, Merauke Regency has been established as the center for food and energy development known as "Merauke Integrated Food and Energy Estate-MIFEE". In accordance with the pattern of Merauke District area, the land area of Merauke Regency is 4,670,163 ha. That area has been allocated for the protection area of 2,455,694 ha and for the investment of 1,598,822 ha. This area was previously allocated to support the national interest of making Merauke District as the center of the MIFEE program. [5]

The declaration of the implementation of the national barn policy has an impact on the rights of indigenous Marin Anim people who inhabit their customary environment. Given this policy will be a problem in terms of the release of the customary rights / customary land of indigenous people of Marin Anim. National legal politics provides recognition of the indigenous rights of the indigenous peoples in Indonesia so that there is a need for mutual agreement without coercion in the case of the release of customary land ownership rights of indigenous peoples. It is important to agree that there should be no excessive land exploitation related to the customary use and the ownership conservation of Marin Anim indigenous people.

The natural damage in the customary territory of Anim people in Merauke becomes a concern of the community, local government, central government and the environmentalists. Various cases of environmental destruction occur at this time, both in the national and international scope. All of the cases are caused by human behavior and the regional and economic development.

By observing the existing conditions, the existence of the rights protection of indigenous and tribal peoples, in terms of the ownership of the environment and the natural resources of indigenous peoples, requires a mechanism to resolve the indigenous peoples' customary land rights issue in obtaining clear information for their survival. This mechanism is known as the Free and Prior Informed Consent (FPIC) Principles. [6]
To find out more about the politics of environmental law and the protection of indigenous peoples' rights in Indonesia, this paper discusses two main issues: first, how is the politics of environmental law and protection of the rights of indigenous peoples Marind Anim based on FPIC principles? and second, how does FPIC function as the concept of environmental policy towards the rights protection of Marind Anim indigenous people?

This paper aims to examine and analyze the problems of environmental law politics in Indonesia in the effort of protecting the customary rights of Marin Anim indigenous people based on FPIC principles. Besides reviewing the study of Indonesian law, this paper also reviews the international legal policy that regulates environmental law policy and the customary rights protection of the rights of indigenous peoples in the world in an effort to realize low carbon / low carbon community development in the development process.

\section{Method}

This is a normative research which uses primary law material, secondary law material and tertiary law material to review the data. The data that are based on the primary legal material are the legal principles, principles of law and legislation that exist in Indonesia and internationally. The secondary law material are the data obtained from books, journals, legal studies, and scientific texts. Then, the tertiary law material is the legal dictionary, the language dictionary which are used to conclude the meaning of this paper. The data obtained is processed, studied and analyzed by using analytical descriptive method, in which the overall data is described and analyzed thoroughly and systematically so as to obtain clear and accurate results.

\section{Discussions}

\subsection{Environmental Law Politics in Indonesia and the International World}

According to Mahfud MD, Politics of law is the official policy line of the law that will be enacted both as the new legal acts and the replacement of old law, to achieve the state goals. [7] Legal politics in Indonesia is the direction of the basic policy of state administration in the field of law sourced from Pancasila, the 1945 Constitution of the Republic of Indonesia and the values prevailing in society to achieve the intended goals of the state. [8] The legal politics of a country is different from other countries. This is due to the differences in the historical development, the state views, the culture, and the political will of every government. Thus, it can be said that politics of law only applies to certain countries and it is not universal. However, it does not mean that the legal politics of a country ignore the existence of the politics of international law. The politics of law of a country must remain aligned and consistent with the politics of international law. 


\subsubsection{Indonesian Legal Politics}

Based on the concept of political politics discussed previously, in this study, the concept of Indonesian environmental law politics in general can be interpreted a concept of policy direction issued by the Indonesian government in determining the renewal and the development of law in accordance with the needs of environmental law. The legal basis of all policies in Indonesia today is the 1945 Constitution of the Republic of Indonesia as the basic norm in the management of the environment and natural resources.

The Constitution of the 1945 Constitution of the Republic of Indonesia has the foundation for the management of the environment and natural resources in several articles namely Article $28 \mathrm{H}$ paragraph (1) and Article 33 paragraph (3), (4) and (5) of the 1945 Constitution of 1945.

Based on the provisions of Article $28 \mathrm{H}$ paragraph (1), Article 33 paragraph (3), (4) and (5) of the 1945 Constitution of the Republic of Indonesia, the state law policy that can be related in terms of environmental management and the utilization of natural resources and the protection of customary community rights of Malin Anim are:

1. Environmental management and the utilization of natural resources owned by indigenous people of Malind Anim must be put within the framework of recognition, protection and fulfillment of human rights as the state citizens of the environment. In other words, Malind Anim customary rights cannot be sacrificed due to the implementation of the development and the utilization of natural resources.

2. The rights protection of Malind Anim indigenous people and the management of the environment and the utilization of natural resources is the responsibility of the state, so that the state has an obligation to make the rules and policies on the utilization of natural resources and environment based on indigenous local wisdom.

3. The philosophical and sociological basis of people's prosperity is the utilization of environmental management and natural resources for the people's prosperity. Thus, it becomes a basis for ensuring that Malind Anim indigenous people gain prosperity.

4. Environmental management and the utilization of natural resources is a means to achieve environmentally sustainable development, in the sense that the objectives of environmental management and the utilization of natural resources cover not only the prosperity of the people, but also the aspects of environmental sustainability and national economic progress.

5. There is a delegation of further arrangements on environmental management by law.

Law No. 32 of 2009 provide an emphasis on environmental protection and environmental management. Law No. 32 of 2009 gives special attention to the requirements of the arrangement that aims to provide assurance for the realization of sustainable development and ensures that the environment can be protected from businesses or activities that cause damage or pollution to the environment.

The rights protection of the indigenous peoples on the environment and management of natural resources is also regulated in Law No. 32 Year 2009. The regulation is contained in Article 63 paragraph (1) letter t, Article 63 paragraph (2) letter n, and Article 63 paragraph (3) letter $\mathrm{k}$.

To achieve the objectives, Law No. 32 of 2009 establishes a number of legal instruments for the prevention of environmental pollution and/or damage as set forth in Article 14, namely Strategic Environmental Assessment (KLHS), layout, quality standard of the environment, standard criteria for environmental damage, AMDAL, Environmental Management Efforts and Environmental Monitoring Efforts (UKL-UPL), licensing, Environmental Economic Instruments, Environmental Based Legislation, Environmental Based Budgeting, Environmental Risk Analysis, Environmental Audit, and other instruments according to the needs and development of science.

KLHS occupies the top position in the prevention of environmental pollution. An emphasis on the principle of environmental protection is also evident from the existence of two permit levels which must be fulfilled by every person or business actor/activity related to environmental management namely the existence of the obligation to obtain environmental permit in advance as a condition for obtaining business license and/or activity. In addition to the prevention instruments, law enforcement instruments (administrative, civil and criminal) are also enforced along with the administrative sanctions, indemnification and criminal sanctions.

With the existence of KLHS, indigenous people of Marin Anim have the power of law before their environment/ environment of customary rights is managed by another person or business actor. The efforts to obtain the permits must meet the requirements of indigenous Marind Anim (Customary License) and government permits (Business License).

The enactment of Law No. 32 Year 2009 strives to ensure the protection of the environment and the management of natural resources and the rights of indigenous people of Marin Anim, in a sustainable, environmentally sound, and based on the local wisdom through policies, plans and development programs, or on the environmental studies for activities or business.

\subsubsection{Indonesian Politics of Law and International Politics of Law in the environmental field.}

The Stockholm Declaration of 1972 on International Environmental Principles is the basis of international environmental law. The Stockholm Declaration of 1972 has influenced the formation of environmental law in the international world.

The meeting agreed upon a Declaration containing 26 principles concerning the environment and 
development; an Action Plan with 109 recommendations, and a Resolution. [9]

In the environmental field, there is the Convention on Biological Diversity (1992), the Rotterdam Convention on Prior Informed Consent Procedures for Pesticides and Types of Hazardous Chemicals in the International Trade (1998). Article 15 paragraph 5 of the Convention on Biological Diversity states.

In the case of indigenous peoples, there is the International Labor Organization's International Convention No. 169 on Indigenous and Tribal Peoples (ILO Convention 169) and the United Nations Declaration on the Recognition of Indigenous Peoples' Rights. Than United Nations Declaration on the Recognition of the Rights of Indigenous Peoples in Article 10, Article 11 paragraph 2, Article 28 paragraph 1, Article 29 paragraph 2, and Article 32 paragraph 2:

Based on Indonesia's membership in the UN, it is natural that Indonesia ratifies the international treaties or conventions relating to environmental protection and natural resource management and recognition of the rights of indigenous peoples to their customary territories/customary environments.

\subsection{Principles of Free and Prior Informed Consent as the concept of environmental policies and natural resources management on the rights protection of Marind Anim indigenous people.}

FPIC (Free and Prior Informed Consent) is a mechanism or process that allows people to "agree" or "disagree" upon an activity, project or policy to be implemented in the community's living space as it may potentially give impact on the land, power and community life. [10]

In the FPIC concept, there are four important elements or principles, namely Free, Prior, Informed and Consent that apply cumulatively (together). Definitively these four things can be interpreted as follows: [10]

1) Free means that indigenous peoples give consent or decide not to approve an activity plan, project or policy without any coercion from any party. Indigenous peoples are free from pressure, threats to argue; society is not under the pressure of time and place to negotiate; and indigenous peoples are also free to choose who should represent them.

2) Prior means that the decision is made before the policy or activity is done. However, in urgent circumstances, the decision of the people may also be made when the activity in progress.

3) Informed means that prior to the decision-making process, the people must be fully informed in the language and a way that is easily understood by the people. Information should be shared by personnel who understand the local cultural context, can speak the local language and incorporate aspects of capacity building for the local people. Information should be comprehensive and objective including potential social, political, cultural and environmental impacts and provide information to the public about potential gains or losses to be received by the people before approval is given.
4) Consent means that a decision or agreement is reached through an open and gradual process that respects the customary or local law collectively with all their own authority.

The principle of free, prior, and informed consent is one of the breakthrough innovations in the recognition of indigenous and tribal peoples in the sphere of participation. This principle has been recognized internationally, especially by the United Nations Declaration on the Rights of Indigenous People (UNDRIP). [11] Forest People Programme on its official page suggests that: [12]

'Free prior and informed consent' (FPIC), is the principle that a community has the right to give or withhold its consent to proposed projects that may affect the lands they customarily own, occupy or otherwise use. FPIC, for years advanced by FPP, is now a key principle in international law and jurisprudence related to indigenous peoples.'

As stated by Anderson in his book, Free, Prior, and Informed Consent: Principles and Approaches for Policy and Projects (2011), FPIC procedures will rely heavily on indigenous customary traditions, making it impossible to create a FPIC procedure that applies to all and recognized universally. Nevertheless, it is still possible to identify the key elements in the FPIC process with the record that this should be kept in line with the process that is accepted by the custom. [13]

The principles of FPIC reflect that a democratic country is obliged to respect and protect the rights of indigenous people, be non-discriminatory, give freedom to the people, including the indigenous peoples, to participate in the development, without pressure and manipulation. Protecting the rights of indigenous peoples on the land, forests and so forth when dealing with natural resource management investments is very important. Indigenous peoples should not be imposed by either government or companies to agree on an investment offer before knowing the details, including the risks that will be their burden when the investment is in progress. Basically, people must know first without any element of coercion or pressure. Therefore, they can make their own decisions freely to either accept or reject an investment policy. If the community's decision is to refuse, then the government and the investor must respect that decision. [14]

An approach by using the application of the Free, Prior and Informed Consent (FPIC) Principles is one way that can reduce the risk of problems between indigenous peoples in the effort to protect the environment and the management of natural resources. The principle of FPIC is the freedom that indigenous peoples have in every investment policy to be undertaken in their region. It means that in terms of civil rights and politics, they are equal in their involvement in making decisions.

According to Ferdianan Saras Dhiksawan, et al., indigenous peoples in Papua generally are: [15]

"Indigenous and tribal peoples involved in development are intended to provide consideration in accordance with local wisdom applicable in the area. But in reality, the current society is not 
involved and only as a spectator especially in Papua. In addition, development in Papua is currently aimed only at infrastructure development but not human development. So, there is no change in the mental attitude of the Papuans. This is evident with the consumptive lifestyle of Papuans. Especially with the policy of aiding the villages, do not give an impact on the mental development of Papuans."

The principle of FPIC is a principle that confirms the right of indigenous peoples to determine what forms of activity they want in their area. Therefore, through an emphasis on the application of FPIC principle, it means that indigenous peoples have the right to obtain information before an investment program is implemented in their area and based on that information they have the freedom without coercion to declare whether they agree or disagree on the investment to be implemented.

Therefore, outsiders who want to invest in indigenous peoples' neighborhoods have to deal with the indigenous peoples themselves as legitimate owners. Thus, there will be respect for the rule of law or values that live within the community of customary law itself.

By implementing the FPIC principles, it means that indigenous and tribal peoples have the right to accept or reject investments in their customary lands and territories and they are entitled to determine the conditions for the realization of projects based on their collective decisions. The most important is the affirmation that indigenous and tribal peoples should not be forced to move from their lands and territories. No relocation shall be possible without the free, prior and informed consent and after a fair and reasonable compensation agreement and where possible with the option of returning to their land. The existence of this principle emphasizes the respect for the rights and values of local wisdom and the best solution to the mastery of environmental protection and management of natural resources owned by indigenous people of Marind Anim.

\section{Conclusion}

The politics of environmental law in Indonesia is strongly influenced by the existence of international environmental law politics. The existence of environmental law in Indonesia cannot be separated from the international agreements or declarations on the environment, and the general principles on environmental protection and natural resource management in the international community.

Protection of Indigenous People of Malin Anim on their environment and natural resource management based on FPIC is a concept that protects the interests of indigenous Marin Anim people, in which there is recognition and respect for indigenous people of Marind Anim who have the right to participate freely and without coercion to get the information to know the procedure of an activity related to its customary rights.

\section{References}

[1] AMAN. Pengakuan Setengah Hati terhadap Penjaga Hutan Terbaik. (Jakarta: Aliansi Masyarakat Adat Nusantara Journal, 2015).

[2] E. Nurmardiansyah. Eco-philosophi dan implikasinya dalam politik hukum lingkungan di Indonesia. pp. 70-104. (Melintas 30.1.2014)

[3] A. Toffler, Future Sbock. pp. 3. (New York: Bantam Books, Inc, 1972)

[4] A. Roziqin. Environmental Policy of Mangroves Management in Rembang Regency. pp.2. E3S Web of Conferences 31, 09002 (2018).

[5] https://www.wwf.or.id/?40183/12-Juta-Ha-LahanMerauke-untuk-Lumbung-Pangan-Nasional

[6] Dewan Kehutanan Nasional dan UN-REDD Programme Indonesia. Rekomendasi Kebijakan: Instrumen Free, Prior, Informed Concent (FPIC) Bagi Masyarakat Adat dan atau Masyarakat Lokal yang Akan Terkena Dampak dalam Aktivitas Redd + di Indonesia. pp.3 (Jakarta: DKN, 2011)

[7] M. Mahfud MD. Politik Hukum Indonesia, pp. 1 Jakarta: Rajawali Pers, Edisi Revisi. (2011)

[8] J. J. J. Kalalo. Politik Hukum Perlindungan Hak Ulayat Masyarakat Hukum Adat Di Daerah Perbatasan. pp. 93. Makassar: Universitas Hasanuddin, Disertasi. (2018)

[9] wikipedia.org. United Nations Conference on the Human Environment

[10] Dewan Kehutanan Nasional dan UN-REDD Programme Indonesia. Rekomendasi Kebijakan: Instrumen Free, Prior, Informed Concent (FPIC) Bagi Masyarakat Adat dan atau Masyarakat Lokal yang Akan Terkena Dampak dalam Aktivitas Redd+ di Indonesia. pp.13. Jakarta: DKN (2011),

[11] J. Headley. Public Participation in Foreign Policy. pp. 176. United Kingdom: Individual Chpapten. (2012)

[12] C. M. Doyle. Indigneous People: Title to Territory, Rights, and Resources. pp. 181. London: Rouletdge. (2015)

[13] P. Anderson, Free, Prior, and Informed Consent: Principles and Approaches for Policy and Project Development, hal. 3. (Bangkok, GIZ \& RECOFTC, 2011)

[14] D. S. Nababan. Perlindungan Hukum terhadap masyarakat adat menurut the United Nations. pp. 1-15. JOM 2, 2 (2015)

[15] F. S. Dhiksawan, S. P. Hadi, A. Samekto, D. P. Sasongko. Indigenous Peoples Involment At The Environmental ImpactAssessment (EIA) Process in Tabi Mamta Area Of Papua Province. pp. 3-4. E3S Web of Conferences 31, 08017 (2018). 